\title{
PEMBANGUNAN JARINGAN RT-RW NET BERBASIS MIKROTIK DI DESA SUKODONO KECAMATAN DAMPIT KABUPATEN MALANG
}

\author{
Bayu Ilhami Hariswara ${ }^{1}$ \\ Citra Kurniawan $^{2}$ \\ Sekolah Tinggi Teknik Malang \\ hariswaraa@gmail.com ${ }^{1}$ \\ airakurniawan@gmail.com²
}

\begin{abstract}
Abstrak: RT-RW Net adalah Solusi untuk memberikan layanan jaringan internet dengan biaya yang relatif murah, Khususnya di daerah yang masih belum tersedianya jaringan internet. Dalam pembangunan jaringan RT-RW Net ada faktor-faktor yang melandasi dalam proses pembangunanya, dan juga metode-metode yang digunakan untuk pengembanganya. Dalam pembangunan Jaringan RT-RW net ini menggunakan Mikrotik sebagai lalu lintas jaringan, seperti manajemen badwith, Pemberian IP (DHCP). Dibutuhkan juga perangkat-perangkat jaringan seperti modemdan station sebagai koneksi ke ISP, Access Point sebgaia koneksi wireless ke client dan Tower untuk memperluas area jangkauan jaringan ke para client. Dalam penyelesaian pembangunan Jaringan RT-RW Net Di Desa Sukodono ada beberapa tahap yang harus dilakukan yaitu : Menentukan area akses jaringan dan tempat server RTRW Net, menentukan kebutuhan alat yang akan dipakai, konfigursai mikrotik, dan pengujian terhadap jaringan yang telah dibangun (implementasi).
\end{abstract}

Kata Kunci: Jaringan, Wireless, Mikrotik, RT-RW Net.

Teknologi informasi dan telekomunikasi berkembang sangat pesat, hal itu menyebabkan setiap orang harus mengikuti perkembangan teknologi informasi dan telekomunikasi. Setiap Orang membutuhkan teknologi informasi dan telekomunikasi dalam memenuhi dan menemani aktivitas sehari-hari. Orangorang mulai berlomba untuk mendapatkan akses yang murah, cepat dan efesien. Namun saat ini akses teknologi khususnya internet masih sulit untuk didapat di daerahdaerah tertentu seperti pedesaan, saat ini cenderung jaringan internet masih mencakup daerah-daerah diperkotaan dan juga biaya yang relatif mahal untuk mempunyai sebuah jaringan internet, padahal kebutuhan akan koneksi internet yang bisa mencakup daerah-daerah pedesaan dan relatif murah sangat diinginkan oleh masyarakat.Kesenjangan akses teknologi khususnya internet ini terjadi begitu jauh antara penduduk di pedesaan dan di perkotaan, hal ini membuktikan masih kurangnya pemerataan pembangunan akses teknologi terutama di pedesaan.

$$
\text { Jaringan internet sudah menjadi }
$$
kebutuhan setiap orang pada masa sekarang ini, Dalam perkembanganya jaringan internet khususnya teknologi wifi sudah semakin marak dalam penggunaan sehari- 
hari, baik komunikasi antar perkantoran maupun untuk komunikasi personal. menurut Herny (2008), Jaringan internet di dalam perkantoran digunakan untuk membuat jaringan antar gedung. Sedangkan untuk kebutuhan personal biasanya digunakan untuk menghubungkan antara BTS suatu penyedia internet dengan komputer personal yang ada di rumahnya. Semakin berkembangnya kebutuhan akses internet di masyarakat maka muncul dan maraknya akses internet murah yang biasa di sebut "RT-RW net" (Herny, 2008).

RT-RW Net merupakan salah satu trend perkembangan teknologi informasi yang memberikan fasilitas internet seperti halnya warnet tetapi dengan cangkupan yang lebih luas. Di Indonesia internet sudah menjadi kebutuhan pemerintah, perusahaan, pendidikan maupun perseorangan. Dengan menggunakan internet, pemerintah bisa memberikan informasi kepada masyarakatnya baik dalam bentuk website maupun aplikasi. Untuk dunia pendidikan, Pelajar dan mahasiswa banyak memanfaatkanya sebagai sumber ilmu pengetahuan alternatif. Mereka bisa memperoleh materi pelajaran atau bahan kuliah yang belum tentu didapat dibangku sekolah maupun kampus. Beberapa situs bahkan menyediakan free journal (Prasetyo, 2015).

Router adalah sebuah perangkat yang akan melewatkan paket IP dari suatu jaringan ke jaringan yang lain. Dengan berbagai fasilitas yang dimiliki router, permasalahan pada jaringan komputer akan bisa terjawab. Menurut Junaidi (2014),mikrotik router OS adalah sistem operasi dan perangkat lunak yang dapat digunakan untuk menjadikan komputer manjadi router network, mencakup berbagai fitur yang dibuat untuk ip network dan jaringan wireless, cocok digunakan oleh ISP dan provider hotspot.sistem operasi yang dikhususkan untuk sebuah networking. Sistem operasi ini cukup handal dalam melakukan kerjanya sebagai router, seperti pengaturan gateway server, limit bandwidth, hingga pada hotspot.

Dari permasalaan diatas, maka peneliti melakukan penelitian untuk dikembangkan suatu perancangan dan pembuatan system jaringan yang dapat menyediakan sarana koneksi internet yang bisa menjangkau daerah pedesaan dan denga biaya yang murah. karena masih jarang dan mahal akses internet dikalangan masyarakat khususnya dipedesaan, maka peneliti akan mengembangkan sebuah sistem jaringan yaitu "Pembangunan Jaringan Rt-Rw Net Berbasis Mikrotik Di Desa Sukodono Kecamatan Dampit Kabupaten Malang”.Dengan pembangunan jaringan RT-RW Net berbasis Mikrotik Di desa Sukodono kecamatan Dampit Kabupaten Malang, diharapkan mampu menjadi alternatif untuk mendapatkan jaringan internet murah dikalangan masyarakat Desa Sukodono. 


\section{Rumusan Masalah}

Berdasarkan uraian latar belakang di atas, maka penelitian ini memilikibeberapa rumusan masalah diantarana adalah sebagai berikut:

1. Apa yang dibutuhkan untuk merancang dan membangun jaringan Rt-Rw Net berbasis mikrotik.

2. Bagaimana merancang dan membangun jaringan Rt-Rw Net berbasis mikrotik.

3. Bagaimana implementasi sistem jaringan Rt-Rw Net berbasis mikrotik di Desa Sukodono kecamatan Dampit Kabupaten Malang.

\section{Tujuan Penelitian}

Tujuan dari Penelitian dan perancangan jaringan RT-RW Net ini antara lain adalah :

1. Mengetahui apa yang dibutuhkan untuk merancang dan membangun jaringan RT-RW Net berbasis mikrotik.

2. Merancang dan membangun jaringan RT-RW Net berbasis mikrotik.

3. Implementasi sistem jaringan RTRW Net berbasis mikrotik di Desa Sukodono Kecamatan Dampit Kabupaten Malang.

\section{METODE}

Dalam penelitian ini, menggunakan pendekatan terhadap model Network
Development Life Cycle (NDLC), Menurut (Rawles, 2001), NDLC merupakan model kunci dibalik proses perancangan jaringan komputer, NDLC merupakan model yang mendefinisikan siklus proses perancangan atau pengembangan suatu sistem jaringan komputer. NDLC juga mempunyai eleme yang mendefinisikan fase, tahapan, langka atau mekanisme proses spesifik.

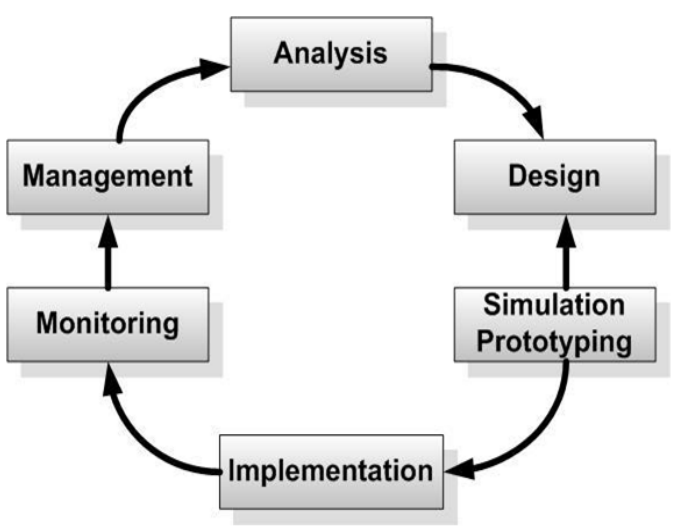

Gambar 1 Metode NDLC

Sumber : (http://library.binus.ac.id/)

\section{HASIL DAN PEMBAHASAN}

\section{Analisis Penelitian}

Tahap perancangan dan pembangunan sistem jaringan RT-RW Net berbasis mikrotik di Desa Sukodono pertama adalah observasi untuk menentukan topology jaringan yang akan dibuat, tempat server dan analisis kebutuhan sistem, penentuan tempat server dilakukan untuk mempermudah jangkauan dari ISP ke Server maupun dari server kepara client. Setelah tempat server ditentukan, kemudian dilanjutkan dengan 
pembangunan sistem jaringan RT-RW Net dan teruskan kepada para client.

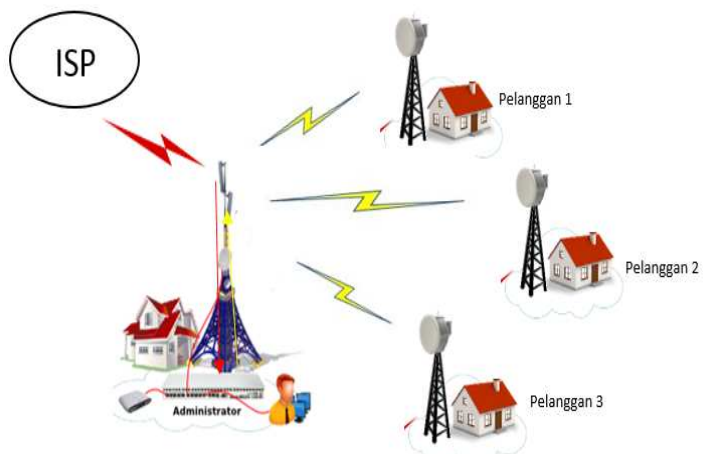

Gambar 2 Topology Jaringan

\section{Implementasi Sistem Jaringan}

Setelah analisis perancang sistem telah dilakukan maka tahap selanjutnya adalah implementasi dan pembahasan. Tahap ini adalah tahap penerapan yang sudah dirancang dengan melakukan penentuan tempat server yang akan digunakan, Pemasangan alat-alat yang sudah di analisis dan konfigurasi pada router mikrotik sehingga dapat diterapkan pada jaringan.

\section{Penentuan Tempat Server}

Langkah awal yang dilakukan untuk membangunan sebuah sistem jaringan RTRW Net adalah dengan menentukan ISP dan tempat server yang akan dibangun, pada pembangunan server Jaringan di Desa Sukodono ini menggunakan penyedia layanan dari telkom, setelah penyedia layanan tersedia kemudian dilanjutkan dengan penetuaan koordinat tempat server yang akan dibangun. Untuk penentuan tempat sever ini dilakukan dibeberapa titik didesa sukodono dan dipilih dengan ketentuan minimnya halangan dari penyedia jaringan ke server.

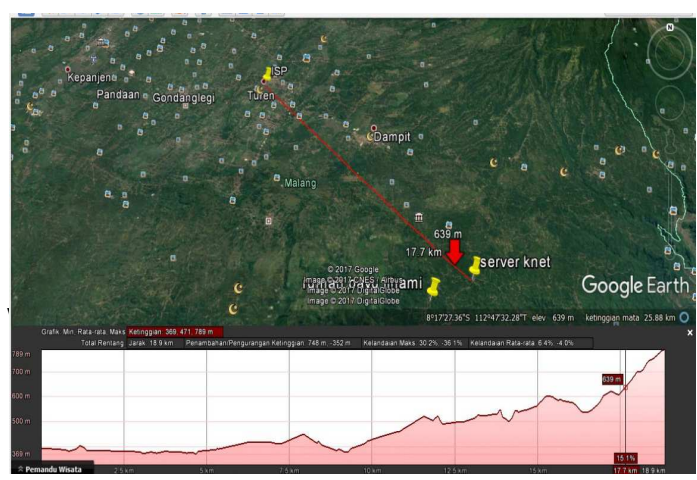

Gamba 3 Peta ISP Ke Server

Setelah tempat server ditentukan, maka selanjutnya adalah pemasangan hardware alat-alat yang dibutuhkan. Tower dibutuhkan untuk mempermudah dan memperluas jangkauan dari penyedia layanan jaringan ke server, maupun dari tempat server ke para client.

Tower yang dibangun pada server ini menggunakan 3 tiang penyangga (triangle) dan memiliki ketinggian 11 meter. Pada tower ini juga pemasangan alat-alat dilakukan, powerbeam, acesspoint dihubungkan ke poE kemudian dari poE dialirkan ke listrik dan mikrotik.

\section{Konfigurasi Mikrotik}

Konfigurasi mikrotik dilakukan agar bisa digunakan routing, server hotspot, mengatur bandwith dan penggunaan tool user manager untuk sistem voucher dan radius. Untuk memulai konfigurasi dengan menggunakan winbox, administrator harus login dengan mas-addres atau ip addres.

Ada beberapa konfigurasi yang harus dilakukan seperti Setting IP, Konfigurasi DNS Server, Firewall NAT, DHCP Server, 
Hotspot, Hotspot Ip Binding, Bandwith, Radius dan Userman.

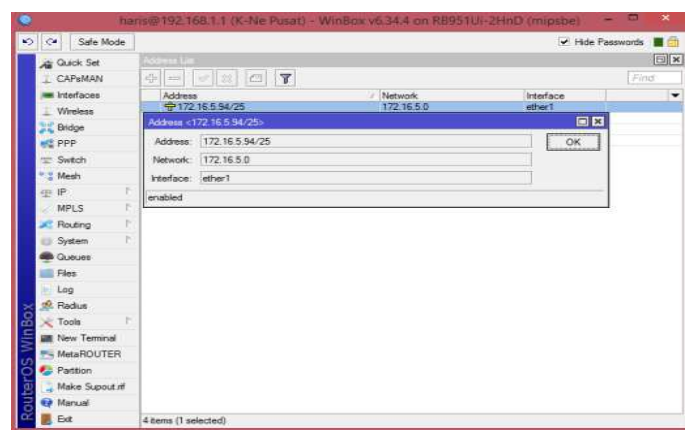

Gambar 4 Setting IP

Setting Ip Adress public pada ether 1 ini digunakan untuk menurunkan internet yang telah diterima ke mikrotik untuk kemudian diolah dan dialirkan kepada acess point yang akan disebarkan kepada para client.

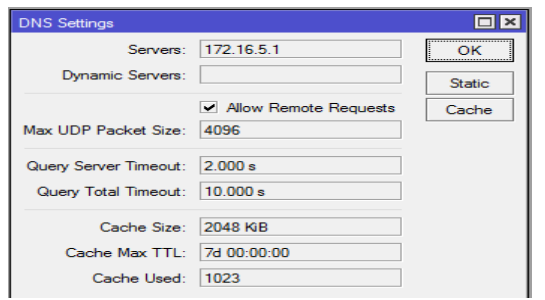

Gambar 5 DNS Server

dns sever yang digunakan harus sesuai dengan yang ada pada penyedia layanan jaringan (ISP).

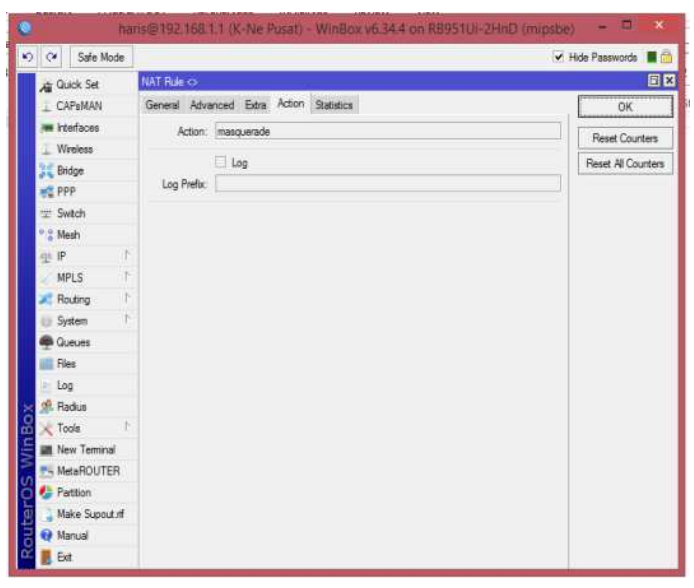

Gambar 6 NAT

Setting firewall dilakukan untuk menghubungkan jaringan public / internet pada mikrotik kepada jaringan local dipc/laptop yang digunakan.

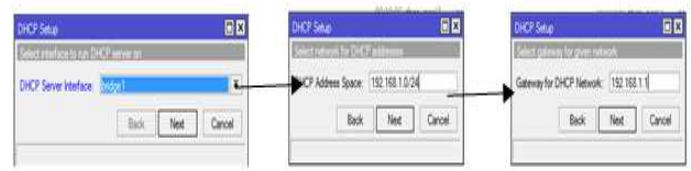

Gambar 7 DHCP Server

Setting DHCP Server dilakukan untuk memberi pinjaman Ip addresss ke host yang ada, jadi ini dilakukan untuk memeberi layanan dari tempat server kapada para pengguna yang ada.

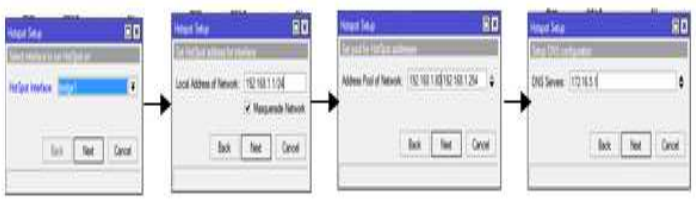

Gambar 8 Setting Hotspot

setiing hotspot dilakukan untuk knfigurasi jaringan yang hanya bisa digunakan dengan usrname dan pasword

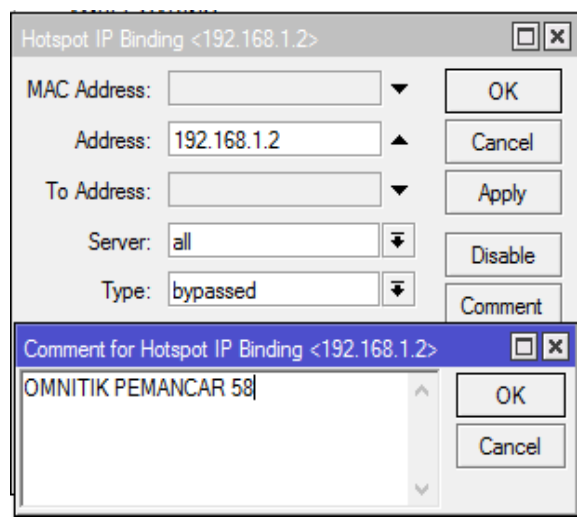

Gambar 9 Hotspot IP Binding

Hotspot ip binding ini dilakukan untuk memberikan ip pada acess point dan pada tiap client yang terdaftar. 


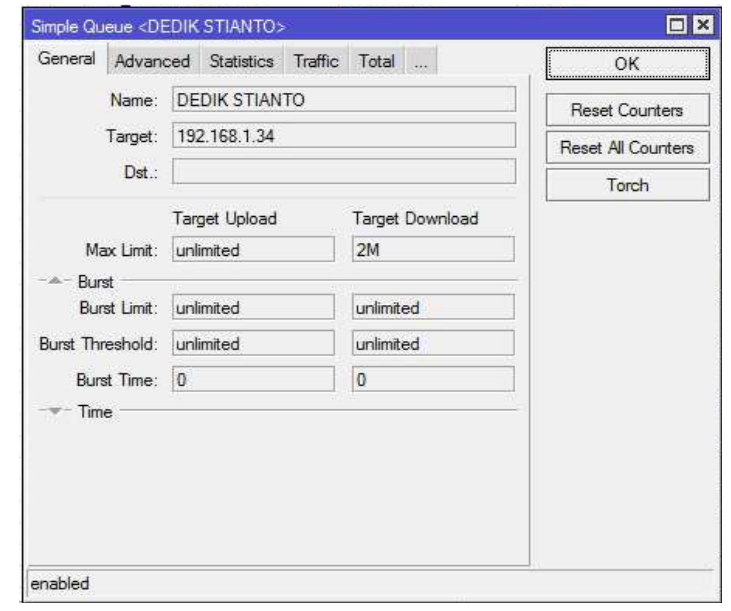

Gambar 10 Bandwith Pelanggan

Limit bandwith pelanggan dilakukan untuk membatasi masing-masing pelanggan sesuai paket yang digunakan.

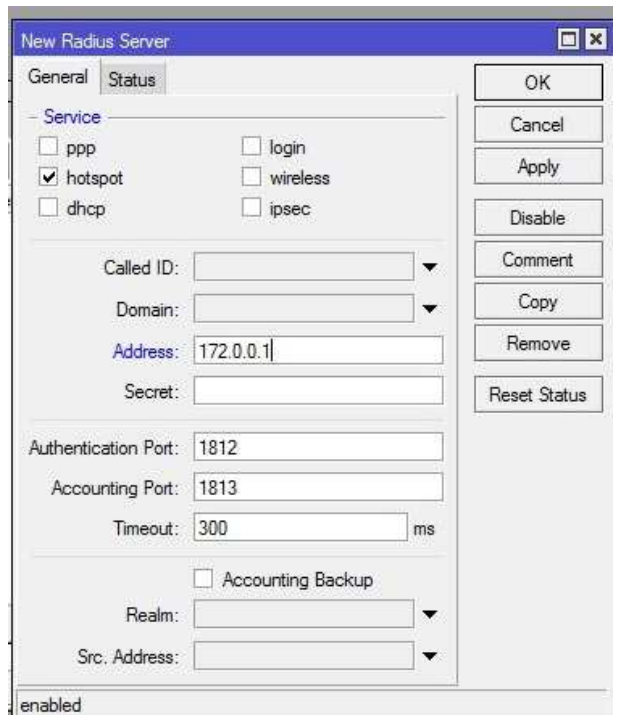

Gambar 11 Radius

Setting radius digunakan untuk bisa membuka usermanager.

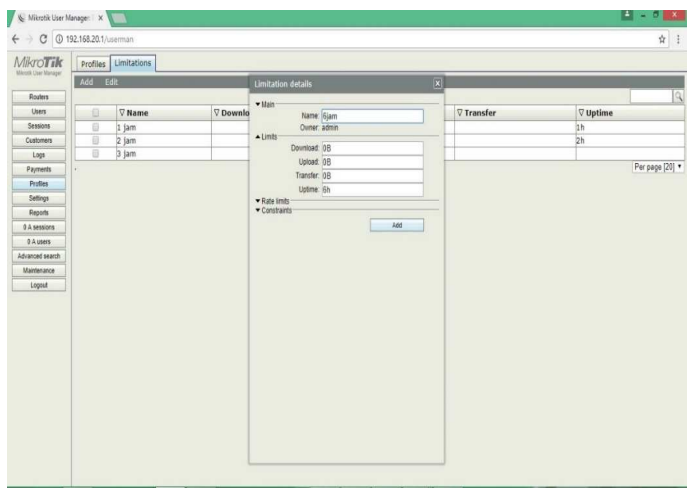

Gambar 12 Usermanager

Fungsi UserManager ini akan menggantikan fungsi Static Lease pada DHCP Server dan fungsi Access List Wireless. Artinya client tidak akan dapat terkoneksi sebelum mac-address terdaftar di Radius Server. Pertama setting terlebih dahulu di sisi Router DHCP \& Wireless sebagai Radius Client.

\section{Pengujian Jaringan}

Pengujian jaringan dilakukan untuk mengetahui coverage atau luasan jaringan yangtelah dibuat, pada gambar dibawah menjelaskan tentang jangkauan jaringan yang telah dibuat dengan cara memetahkan jangkauan sinyal dari server ke client (penerima) didesa Sukodono.

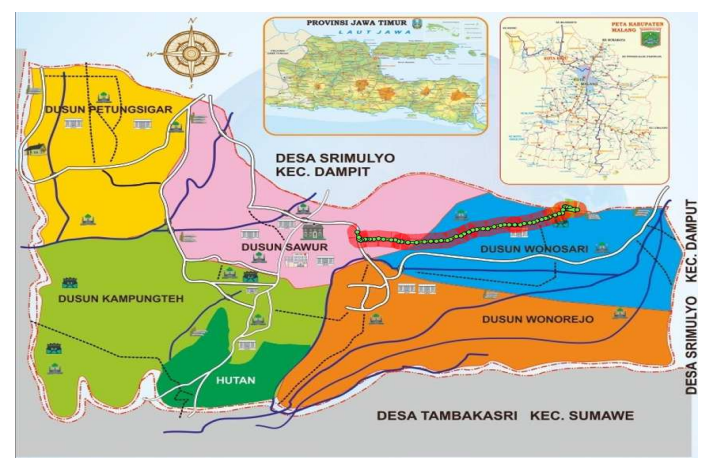

Gambar 13 Pengujian Jaringan

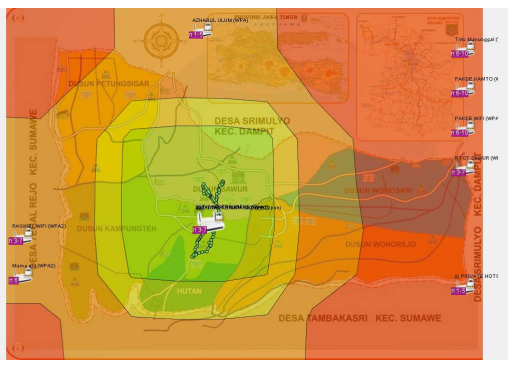

Gambar 14 Hasil Pengujian Jaringan

Pada gambar diatas menjelaskan tentang hasil pengukuran jaringan RT-RW Net di Desa Sukodono, warna hijau 
menunjukan sinyal kuat dan warna merah menunjukan tidak adanya sinyal.

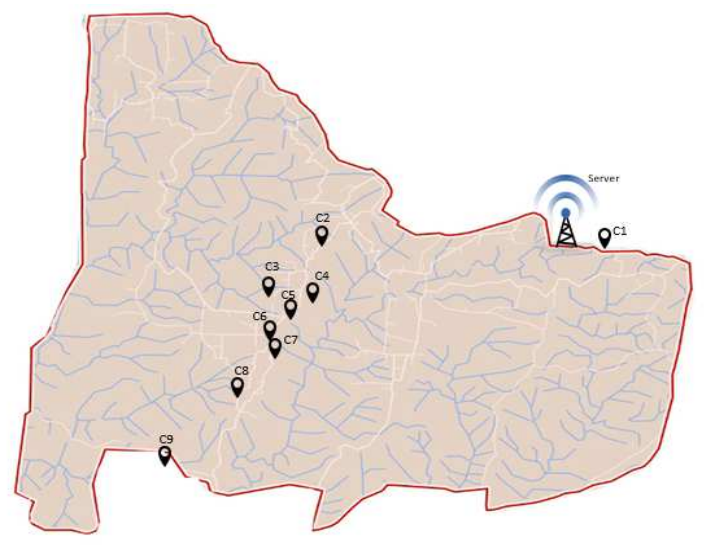

Gambar 15 Peta Jaringan

Pengujian dilakukan dengan menggunakan software ekahau heatmapper untuk melihat seberapa besar jangkauan dan kualitas sinyal yang diterima oleh receiver ( $\mathrm{Rx})$ (Kurniawan, 2016). Proses pengujian ini sangat penting untuk menjaminkan bahwa terjadinya proses koneksi dari Transmitter (Tx) pada Receiver (Rx).

Keterangan

Server : Server RT-RW Net Sukodono (Tx) C1-C9 : Client RT RW Net Sukodono (Rx)

\section{Pengukuran Jaringan}

Pengukuran dilakukakan dengan cara scan jaringan server RT-RW Net Sukodono dengan SSID Bellanetdampit dari tempat client.

Tabel 1 Hasil Pengukuran Server-Clientt

\begin{tabular}{|c|c|c|c|c|}
\hline No & Client & Koordinat & $\begin{array}{l}\text { Sinyal } \\
(\mathrm{Dbm})\end{array}$ & $\operatorname{Jarak}(\mathrm{km})$ \\
\hline 1 & Smp Pgri 3 & $8^{\circ} 17^{7} 56.2^{\prime \prime S} 112^{\circ} 47^{\prime} 59.2^{\mathrm{N}} \mathrm{E}$ & -42 & 0,05 \\
\hline 2 & Warkop Arema & $8^{\circ} 17^{7} 59.8^{\prime \prime S} 112^{\circ} 46^{\circ} 58.6^{\prime \prime E}$ & -69 & 1.82 \\
\hline 3 & Rumah Kamto & $8^{\circ} 18^{\prime 2} 26.1^{\prime \prime S} 112^{\circ} 46^{\prime} 46.4^{\prime \prime E}$ & -78 & 2,37 \\
\hline 4 & Rumah Dedik & $8^{\circ} 18^{\prime 2} 29.6^{\prime \prime S} 112^{\circ} 46^{\prime} 43.4^{\prime \prime E}$ & -67 & 2,5 \\
\hline 5 & Mts $\mathrm{AU}$ & $8^{\circ} 18^{\prime} 25.3^{\prime \prime S} 112^{\circ} 46^{\prime} 40.7^{\prime \prime E}$ & -79 & 2,54 \\
\hline 6 & Tiga Putra Percetakan & $8^{\circ} 18^{\prime} 48.2^{\prime \prime S} 112^{\circ} 46^{\prime} 35.1^{\prime \prime E}$ & -71 & 3 \\
\hline 7 & Warkop 4 Saudara & $8^{\circ} 18^{\prime} 49.2^{\prime \prime S} 112^{\circ} 46^{\prime} 35.1^{\prime \prime E}$ & -73 & 3,02 \\
\hline 8 & Raghiel Counter & $8^{\circ} 19^{\prime} 12.4^{\prime \prime S} 112^{\circ} 46^{\prime 2} 22.9^{\prime \prime E}$ & -79 & 3,75 \\
\hline 9 & Warkop Lare & $8^{\circ} 19^{\prime} 48.9^{\prime \prime} \mathrm{S} 112^{\circ} 46^{\prime} 11.8^{\prime \prime} \mathrm{E}$ & -76 & 4,8 \\
\hline
\end{tabular}

\section{KESIMPULAN DAN SARAN}

\section{Kesimpulan}

Berdasarkan hasil dari tahapan pembangunan sistem jaringan RT-RW Net berbasis mikrotik di Desa Sukodono Kecamatan Dampit Kabupaten Malang, maka diambil kesimpulan sebagai berikut:

1. Sistem Jaringan RT-RW Net Berbasis Mikrotik telah berhasil diterapkan di Desa Sukodono Kecamatan Dampit Kabupaten Malang.

2. Dari penelitian ini diketahui bagaimana perancangan dan pembangunan jaringan RT-RW Net berbasis mikrotik, sistem jaringan yang dibangun menggunakan mikrotik sebagai manajemen jaringan, dan winbox digunakan untuk setting pada mikrotik. Jaringan RT-RW Net ini dibangun untuk menyediakan layanan jaringan internet di Desa Sukodono Kecamatan Dampit, dengan biaya yang relatif terjangkau.

3. Mikrotik merupakan sistem operasi yanag dapat membantu meringkankan pekerjaan para administrator jaringan karena kemudahan dalam seeting atau konfigurasinya.

4. Dari penelitian ini diketahui cara kerja sistem jaringan dengan client maupun dengan menggunakan 
hotspot. Dengan cara Client-Server memudahkan pengguna untuk mengakses jaringan di tempat yang diinginkan para client.

Saran

Sistem Jaringan RT-RW Net berbasis mikrotik ini masih banyak yang harus dikembangkan yang tentunya diharapkan untuk menjadi lebih baik. Adapun saran untuk peneliti selanjutnya diantaranya sebagai berikut :

1. Lakukan pengumpulan data dan observasi terlebih dahulu, sebelum membangun sebuah sistem jaringan RT-RW Net, tunjuanya supaya memudahkan dalam membangunan sebuah sistem jaringan.

2. Perlu pemasangan badwith yang besar agar koneksi lebih cepet dengan client yang banyak.

3. Pembatasan client perlu dilakukan demi performa yang maksimal.

4. Penambahan station sebagai pembagi sinyal perlu dilakukakan, untuk mengatasi banyaknya halangan penyebaran sinyal ke para client.

5. Peningkatan keamanan jaringan.

\section{DAFTAR RUJUKAN}

Bina Nusantara, 2011. Network

Development Life Cycle NDLC.

(http://library.binus.ac.id/eColls/eT hesisdoc/Bab2HTML/2013101359I

FBab2001/html, di akses 29 April 2017)

Citraweb Nusa Infomedia.. Mikrotik

Rb951. Diambil Dari

(http://www.mikrotik.co.id/produk_ lihat.php?id=371/, diakses 13 April 2017).

Februariyanti, Herny. 2008, “Internert Murah dengan Membangun Jaringan RT-RW Net”. E-Jurnal

Volume XIII, No.2 : 98-114.

Franky, Adhiputra ricky. 2013, “

Perancangan dan Simulasi RT-RW

Net Dengan Router Mikrotik”.

Volume - No.-

Junaidi. 2015, “ Rancang Bangun Jaringan

Berbasis Mikrotik Di SMP 3

Simpang Teritip". Volume- No.-

Kurniawan, Citra.2016. Optimalisasi

Perencanaan Konfigurasi Wireless

LAN dengan Metode Drive Test

(Studi kasus: Kantor Wireless

Broadband Telkom Malang).

Sinteks: Jurnal Teknik 5(2).

Mulyadi, Ilham \& Joko Dwi. 2015, “ Membangun Jaringan RT-RW Net

Berbasis Hotspot Wifi Sebagai

Solusi Internet Murah Di Rt 13

Cokrodiningrat, Jetis DIY".

Volume- No.- 
Wijayanti, Setya \& Muslihudin. 2013, “

Pembangunan Web Proxy Dengan

Mikrotik Untuk Mendukung

Internet Sehat Di SMK

Muhammadiyah 1 Patuk

Gunungkidul”. Volume- No.- 